\title{
Green Marketing Tools, Religiosity, Environmental Attitude and Green Purchase Behaviour Among Millenials Generation
}

Nihayatu Aslamatis Solekah* Faculty of Economics, Maulana Malik Ibrahim State Islamic University, Indonesia aslamatiss 1@pbs.uinmalang.ac.id

\section{Gancar Premananto}

Faculty of Economic and

Business Airlangga University, Indonesia

\section{Sri Hartini}

Faculty of Economic and

Business Airlangga University, Indonesia

\section{ABSTRACT}

The purpose of the research is to examine relationship between Green Marketing Tools (GMT), Environmental Attitudes (EA), Religiosity and Green Purchase Behavior (GPB) and test Religiosity moderates between Environmental Attitudes (EA) and Green Purchase Behavior (GPB). This study employs samples using a questionnaire instrument. The result of the collected 268 questionnaires of respondents were processed using descriptive and quantitative analysis data using SEM (Strutural Equation Model) analysis techniques with Stata 13 . The results showed that millennial generation in shaping their engagement behavior on environmental issues is influenced by environmentally friendly advertisements, attributes or labels used on a product, then perceptions of environmentally friendly brands and trust in environmentally friendly advertisements, trust in compliance or environmentally friendly labels and brands that are on the products they know. The findings of this study suggest that individual factors in the form of religious and situational factors in the form of green marketing tools in the form of eco labels, eco brands, trusts or trust in eco labels and eco brands, and environmental advertising affect green behavioral.

Keywords: Green Marketing Tools, Religiousity, Environmental Attitude, Green Purchase Behaviour

| Received May 2020 | Accepted November 2020 | Available online December 2020 |

| DOI: http://dx.doi.org 10.18860/mec-j.v4i3.8203

\section{INTRODUCTION}

Environmental degradation is one of important challenges in $21^{\text {st }}$ century. Tanner and Wolfang (2003) states personal consumption mainly caused by excessive consumption is the main factor that make the environmental problem. Schafer et al. (2011) in long term because of the excessive consumption able to endanger the natural environment, but also able to influence the welfare and life quality of consumers. Because of that, in the developed or developing countries it is given emphasis to find a way to decrease the emergence of negative effect from the excessive consumption and buy products that are environmentally friendly. 
It is along with and need no questions about green marketing that become main trend in competitive business. Green marketing practice mostly develops as the results of the sustainable value improvement given by consumers. Without considering the size, companies acknowledge the go green benefit. American Marketing Association in 2009 states that more than half of company marketers think that their company will improve the sustainable effort during 2010 and 2011 (AVS Group) and more than 43 percent of the companies under research stated that heir company will improve the environmentally friendly marketing, along with definition of Grewal and Evy (2008) that green marketing is strategic effort made by company to provide goods and services that environmentally friendly.

Elham and Nabsiah (2011) explains that there is influence of green marketing tools that consist of three dimensions, eco label, eco brand, and environmental ads) toward the actual purchase behavior. There presence of factor analysis result in the research model produce modification of one dimension added in the green marketing tools and given name eco label and eco brand. The investigation toward coefficient from each dimension of green marketing tool showed eco-brand and trust to green label an ecobrand as positive and significant variable relate to the actual purchase behavior, it can be seen that the environmentally friendly branded products have success commercially because have positive image, that direct the consumers to buy and cause the growth for the brand loyalty (Ginsberg and Bloom, 2004).

Soyes (2012) shows that there is significant influence between culture that contains religiosity toward consumers behavior that pro to environment. But inversely proportional between cultural values or religiosity toward environmental attitude. It is not suitable with Droge et al. (1993) that shows the strong interaction between cultural value and environmentalism. Sumarwan (2011) states that religion or religiosity is factor that forms purchase behavior for consumers in Indonesia. Religion is cultural key in environment that is influenced by consumer behavior and finally influence the decision making (Delener, 1994).

Joshi and Rahman (2015) reviewed the results of a study in Scopus journal from 2000 to 2014 concerning factors that affect green purchase behavior and the results showed that there empirical articles influenced by individual factors and situational factors. None of the articles have combined individual factors in the form of religious and situational factors in the form of Green Marketing tools in the form of eco labels, eco brands, trust in eco labels and eco brands, and environmental advertisements. So that this research is expected to fulfill the gap. In addition, no one has tested the religiosity of the millennial generation and uses the dimensions of Glock and Stark (1968) which are widely used in research in a Muslim-majority country.

MeKay (2010) shows although practice and research about green marketing increasingly develops, little academic research that give attention to understand the Millennial generation (also called as $Y$ generation or Eco Generation) to green products (Smith and Brower 2012). Suitable with request Burgess and Streenkamp (2006) to make market research in developing country, the research was done in Indonesia, suitable with the 
opinion of Martin (2012), second wave of developing countries is MIST countries that the economic growing group including Mexico, Indonesia, South Korea, Turkey.

The research developed the research framework to explore the rare construction of the relationship investigation between green marketing tools, religiosity, environmental attitude and green purchase behavior at the millennial generation.

\section{THEORETICAL REVIEW}

\section{Green Marketing Tools (GMT)}

According to Peattie and Crane (2005) in Lee (2008), there is three phases in green marketing. The first phase, during the green marketing phase begun in the industry since 1980s. According to Wong et al. (1996), about 1990 s green marketing enter the second phase, where at the periode, there is specific reaction by marketer. While according to Schrum et al. (1995), progressively marketers understand that the consumers attention, their positive attitude toward environment and green product not directly shown in the purchasing behavior. After 20th century about year 2000 green marketing entered into the third stage. At the phase green marketing has passed through new momentum with the implementation of more advanced technology, stricter governmental regulation and global environment awareness improvement.

Green marketing that generally focused at the persuasive strategy efficiency of cognitive aspect, and believe that the high consumer involvement toward environmental issues is effect from the environmental knowledge improvement (Hartmann and Iba'nez, 2006).

Definition of green marketing according to Stanton and Futrell (1987) is action aimed at replacing the current needs and desire by minimizing the impact toward environment. While according to Ginsberg and Bloom (2004) states that no one marketing tools that suitable for all companies. Strategy should be adapted or different based on the different market and the consumer awareness toward environment.

\section{Relationship Between Environmental Attitude (EA) And Green Purchase Behavior (GPB)}

Dembowski and Hanmer-Lloyd (1994) EA and behavior can be included into environmental awareness concept but not necessarily has relation (Diamantopoulus et al., 2003). The influence of EA is positive and significant statistically has been reported for natural food purchase (Homer and Kahle, 1988), environmentally friendly product purchase (Kalafatis et al, 1999, Kim and Coi 2005, Schlegemileh et al., 1996), and pro environment behavior in general (Aytukkasophlu and Ecevit, 2003; Bamberg and Moser 2007, Fraj and Martinez, 2006, Gaterslebeen et al., 2002; Kaiser et al., 1999, Meinhold and Malkus 2005, Minton and Rose 1997, Roberts 1996). Janson et al. (2010) reports the positive influence of EA at the limiting behavior such as decrease energy consumption and adopt environmentally friendly technology. Kaiser et al. (1999) stated that EA and behavior has weak relationship or not significant caused by the problems with correspondence measurement and the lack of true association. If the attitude and 
behavior not measured at the same specivity level between two variables can cause substantial bias.

At other side, environmentally friendly product often sold in higher price than the conventional product and because of that the consumers have to have high commitment toward environment to purchase it (Mc Carty and Shrum, 2001). So, it is expected that EA and GBP has relationship positively.

$H_{1}$. Green marketing tool (GMT) influences positively to the green behavioral purchase $(G B P)$.

\section{Religiosity has positive relation with environmental attitude (EA) and GPB)}

In the research done previously by Esso and Dibb (2004) entitled religious influences on shopping behavior: an exploratory study about the influence of religiosity toward shopping behavior of 1000 household heads at Maritius (England), states that religiosity variable that has significant influence.

Religiosity is defined as motivation, values, and religious belief (Allport and Ross, 1967). According to Essoo and Dibb (2004) religiosity is how far individual has commitment to certain religious group while according to Delener (1990) main culture force and influence decision making of consumers substantially.

Martin and Bateman (2014) did not find influence of interpersonal religious commitment to the attitude and exocentric behavior. So, it is possible that new article conclude that 'recall to the multi dimensional nature of religiosity and environmental protection, the different research results - statistical analysis 'briarpatch' virtual of multlivariate contrast with coherent summary' (Harper, 2008).

$H_{2}$. Environmental attitude (EA) influences positively to the green behavioral purchase (GBP)

$H_{3}$. Religiosity influences positively to the green behavioral purchase (GBP)

Wicker (1969) at the beginning of research, the relation between attitude and behavior shows low relationship. At other side, Glasman and Albarracin (2006) showed some variability between correlation between attitude and behavior from $-0,20$ to 0,73 . Among the construct that study about the influence of relationship moderation between attitude and behavior is the attitude belief (Fazio and Zanna, 1978), attitude strength (Holland et al., 2002), introspection (Wilson and Dunn, 1986), and self monitoring (Zanna et al., 1980)

For research that integrate moderation into environmental study to understand more about relation between EA and pro environmental behavior such as recycle or green product purchase is rare that found higher correlation between general EA and environmentally friendly behavior at the consumer effectiveness. Then Schultz and Oskamp (1990) found that EA is stronger predictor from the recycling behavior when 
effort needed for the behavior is high, and the relationship is weaker when less effort needed for the behavior.

$H_{4}$. Religiosity influences positively to the environmental attitude (EA)

\section{Conceptual Model}

Based on the consistency theory in the research of behavior (Millar and Tesser, 1989), we suggest that religiosity maybe not only has positife effect at EA and pro environment behavior, but also positively moderating the relationship between both variable. Suitable with the Holy Qur'an, religious belief consistent with pro-EA, we assumed that religiosity will strengthen the relationship between EA and behavior. Specially, the researcher has opinion that it is assumed that there is positive relationship between $E A$ and $G B P\left(\mathrm{H}_{2}\right)$, and positive relationship between religiosity and $E A\left(\mathrm{H}_{3}\right)$ and religiosity and $\mathrm{GBP}\left(\mathrm{H}_{4}\right)$, religiosity will has positive impact at the relationship between $E A$ and $G B P$.

For more explanation can be seen in the Research Concept Framework below

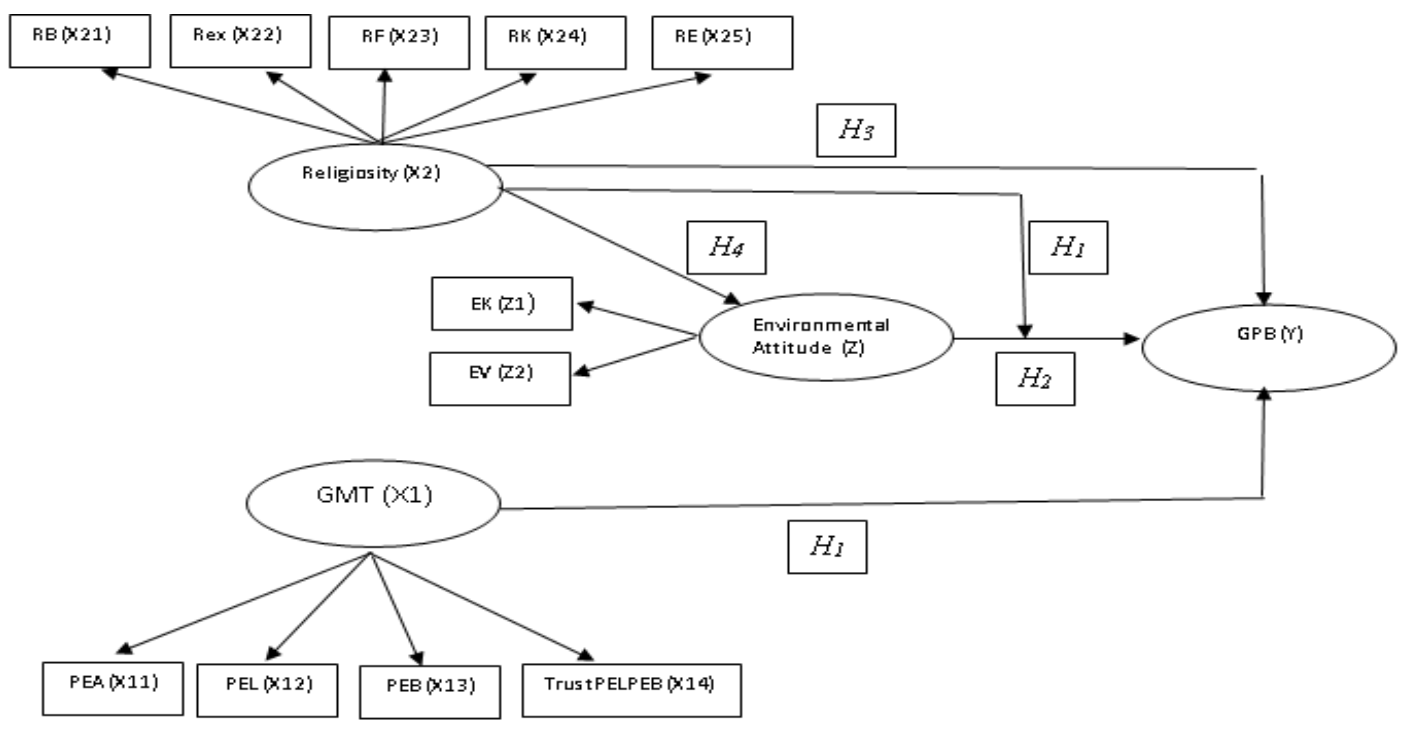

Figure 1. The Conceptual Model

\section{METHODOLOGY}

This type of research was quantitative study using survey approach. The population used in this study were as millennial generation. There are four variables used, (1) Green Marketing Tools that consist of Perception of Environmental Advertisement (Davis, 1994), Perception of Eco labels (Rex and Baumann, 2007), Perception of Eco-brand and Trust in eco label dan eco brand (Chen, 2013). (2) Religiosity (Glock and Stark, 1968), (3) Environmental Attitude (Milfont \& Duckitt, 2010) and (4) Green Purchase Behavior in the millennial generation (Chan, 2001). Based on these variables, then the Instruments are determined. Data collection methods in this study were observation, interviews and questionnaires. The results of the collected questionnaires were processed using 
descriptive and quantitative analysis data using SEM (Strutural Equation Model) analysis techniques. Participants were recruited using a snowball sampling technique (Arnold and Reynolds, 2003) from students at universities in Indonesia. By using a survey approach in the form of a questionnaire. The choice of respondents from students was due to an understanding with the consensus that the millennial generation was a generation born in 1980 until the 1990 (Hood, 2012).

Besides that students are considered to have a sufficient level of knowledge relating to eco labels, eco brands and environmental issues. According to Malhotra in Asnawi and Masyhuri (2011), respondents who will be sampled in a study with a population that is not known to be in number, then determined at least 4 to 5 times the number of items in question. The samples were collected from 268 questionnaires of millennials generation and processed using descriptive and quantitative analysis tools using SEM (Structural Equation Model) analysis techniques with Stata 13.

\section{RESEARCH RESULTS}

\section{Characteristics of Respondents}

In this study, researchers grouped respondents into several characteristics. The first characteristic is based on the sex of the respondents divided into men and women. Based on data processed from the questionnaire, the most respondents are female with number of 169 or about $63,1 \%$. Whereas the male respondents were 99 or $36,9 \%$. The second characteristic is based on the respondents age which is divided into ages 15-25 years, 26-35 years, 36-45 years, and more than 45 years. Based on data processed from the questionnaire, the most respondents are respondents who aged 15-25 years. In accordance with the research object that prioritizes millennial generation. The third characteristic is based on the respondents occupation which are divided into civil servants, private employees, entrepreneurs, students, and others. Based on data processed from the questionnaire, the most respondents were respondents who had occupation as Students/ Students by $88,8 \%$ or 238 respondents. Data on the characteristics of respondentsis as in Table 1.

Table 1. Characteristics of Respondents

\begin{tabular}{llll}
\hline & Criteria & Frequence & Percent \\
\hline Gender & Male & 99 & $36,9 \%$ \\
Age & Female & 169 & $63,1 \%$ \\
& $15-25$ years & 259 & $96,6 \%$ \\
\multirow{3}{*}{ Occupation } & $26-35$ years & 9 & $3,4 \%$ \\
& $36-45$ & years & - \\
& Civil Servant & 3 & $1,1 \%$ \\
& Private employee & 12 & $4,5 \%$ \\
& Entrepreneur & 4 & $1,5 \%$ \\
& Student & 238 & $88,8 \%$ \\
& Others & 11 & $4,1 \%$ \\
& Civil Servant & 3 & $1,1 \%$ \\
\hline
\end{tabular}


Solekah, Premananto, Hartini

Table 2. Description of the Green Marketing Tools

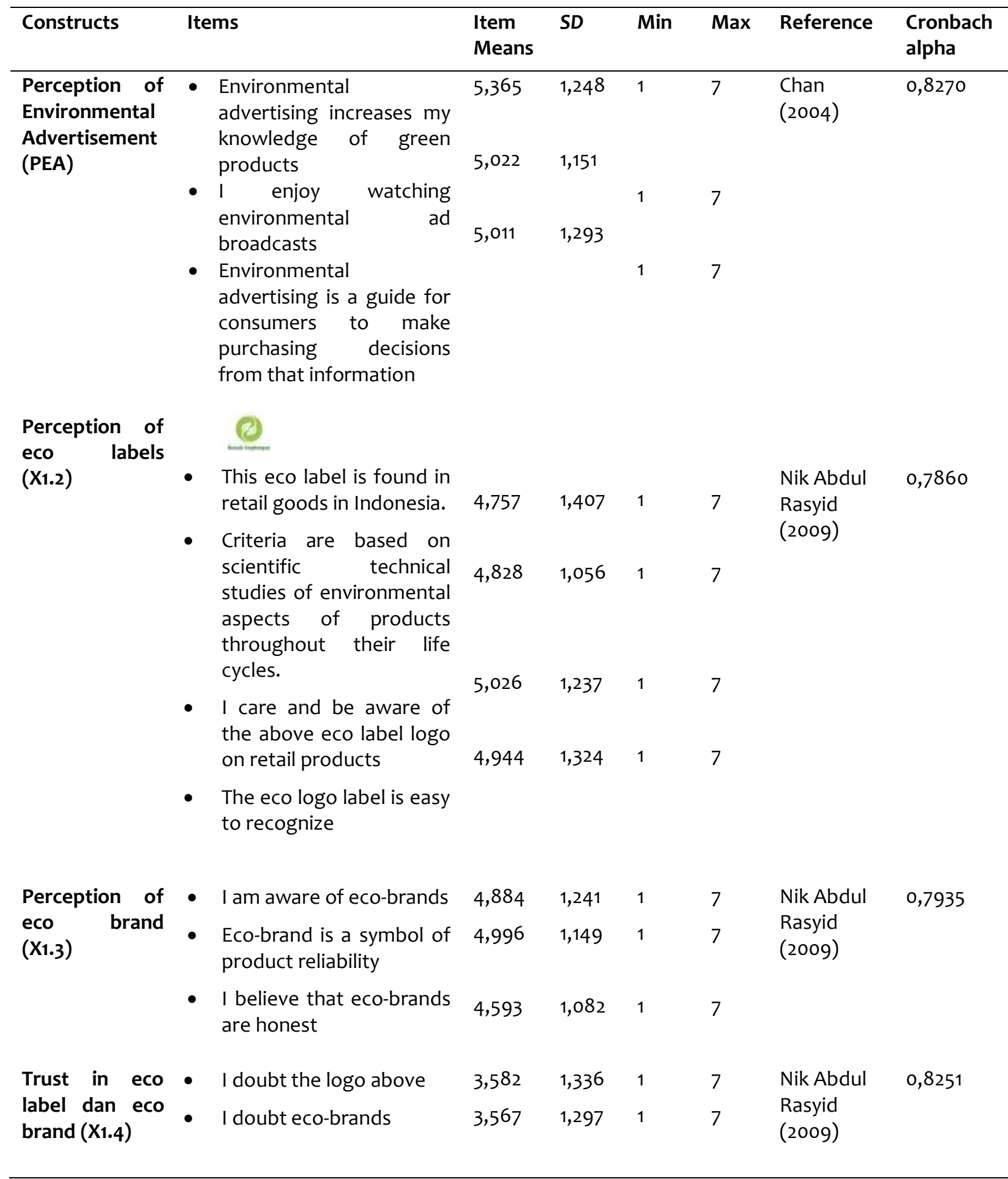


Green Marketing Tools, Religiosity, Environmental Attitude .....

Table 3. Description of Religiosity

\begin{tabular}{|c|c|c|c|c|c|c|c|}
\hline Constructs & Items & $\begin{array}{l}\text { Item } \\
\text { Means }\end{array}$ & SD & Min & Max & Reference & $\begin{array}{l}\text { Cronbach } \\
\text { alpha }\end{array}$ \\
\hline $\begin{array}{l}\text { Ideologis } \\
\text { (religious } \\
\text { belief) (X2.1) }\end{array}$ & $\begin{array}{l}\text { - I believe that my religion } \\
\text { teaches to always } \\
\text { maintain the } \\
\text { sustainability of the } \\
\text { surrounding } \\
\text { environment } \\
\text { - I believe in religious } \\
\text { scriptures there are } \\
\text { orders to protect the } \\
\text { environment }\end{array}$ & 6,268 & 1,409 & 1 & 7 & $\begin{array}{l}\text { Glock, Charles } \\
\text { Y. (1968), } \\
\text { Allport, G.W. } \\
\text { and Ross, J.M. } \\
\text { (1967) }\end{array}$ & 0,9656 \\
\hline $\begin{array}{l}\text { Ritualistik } \\
(\mathrm{X} 2.2)\end{array}$ & $\begin{array}{l}\text { - I practice my religious } \\
\text { teachings for them to } \\
\text { keep their surroundings } \\
\text { - By practicing the } \\
\text { doctrine I have } \\
\text { performed the Lord's } \\
\text { command }\end{array}$ & 5,641 & 1,346 & 1 & 7 & $\begin{array}{l}\text { Glock, Charles } \\
\text { Y. (1968), } \\
\text { Allport, G.W. } \\
\text { and Ross, J.M. } \\
\text { (1967) }\end{array}$ & 0,8975 \\
\hline $\begin{array}{l}\text { Eksperensial } \\
\text { (religious } \\
\text { feeling) } \\
\text { (X2.3) }\end{array}$ & $\begin{array}{l}\text { By being friendly to the } \\
\text { surrounding } \\
\text { environment, I feel calm } \\
\text { and close to religion }\end{array}$ & 5,496 & 1,336 & 1 & 7 & $\begin{array}{l}\text { Glock, Charles } \\
\text { Y. (1968), } \\
\text { Allport, G.W. } \\
\text { and Ross, J.M. } \\
\text { (1967) }\end{array}$ & \\
\hline $\begin{array}{l}\text { Intelektual } \\
\text { (religious } \\
\text { knowledge) } \\
(\mathrm{X} 2.4)\end{array}$ & $\begin{array}{l}\text { - I know that in the } \\
\text { religious scriptures I } \\
\text { explain a lot of orders } \\
\text { and prohibitions to be } \\
\text { friendly to the } \\
\text { environment } \\
\text { - I know that in religious } \\
\text { scriptures there are } \\
\text { orders to preserve } \\
\text { environmental for the } \\
\text { sustainability for } \\
\text { future of future } \\
\text { generations }\end{array}$ & 5,261 & 1,849 & 1 & 7 & $\begin{array}{l}\text { Glock, Charles } \\
\text { Y. (1968), } \\
\text { Allport, G.W. } \\
\text { and Ross, J.M. } \\
\text { (1967) }\end{array}$ & 0,7008 \\
\hline $\begin{array}{l}\text { Religious } \\
\text { effect (X2.5) }\end{array}$ & $\begin{array}{l}\text { - If my behavior causes } \\
\text { damage to the } \\
\text { environment, I am aware } \\
\text { that this has } \\
\text { consequences } \\
\text { - My religion mentions } \\
\text { that damage to the earth } \\
\text { is a result of human } \\
\text { actions }\end{array}$ & 5,816 & 1,355 & 1 & 7 & $\begin{array}{l}\text { Glock, Charles } \\
\text { Y. (1968), } \\
\text { Allport, G.W. } \\
\text { and Ross, J.M. } \\
\text { (1967) }\end{array}$ & 0,8285 \\
\hline
\end{tabular}


Solekah, Premananto, Hartini

Tabel 4. Description of the Environmental Attitude

\begin{tabular}{|c|c|c|c|c|c|c|c|}
\hline Constructs & Items & Item Means & $S D$ & Min & Max & Reference & $\begin{array}{l}\text { Cronbach } \\
\text { alpha }\end{array}$ \\
\hline \multirow[t]{3}{*}{$\begin{array}{l}\text { Environmental } \\
\text { Attitude }\left(\mathrm{X}_{3}\right)\end{array}$} & $\begin{array}{l}\text { - When humans } \\
\text { disturb nature, it } \\
\text { often results in } \\
\text { disastrous }\end{array}$ & 5,798 & 1,386 & 1 & 7 & \multirow[t]{3}{*}{$\begin{array}{l}\text { Kaiser } \\
\text { (1999) }\end{array}$} & \multirow[t]{3}{*}{0,7918} \\
\hline & $\begin{array}{l}\text { consequences } \\
\text { - Humans must live in } \\
\text { harmony with nature } \\
\text { in order to survive }\end{array}$ & 5,925 & 1,380 & 1 & 7 & & \\
\hline & $\begin{array}{l}\text { - Humanity is very } \\
\text { abusing the } \\
\text { environment }\end{array}$ & 4,891 & 1,354 & & & & \\
\hline
\end{tabular}

Table 5. Description of the Green Purchase Behavior

\begin{tabular}{|c|c|c|c|c|c|c|c|}
\hline Constructs & Items & $\begin{array}{l}\text { Item } \\
\text { Means }\end{array}$ & $S D$ & Min & Max & Reference & $\begin{array}{l}\text { Cronbach } \\
\text { alpha }\end{array}$ \\
\hline \multirow[t]{8}{*}{$\begin{array}{l}\text { Green } \\
\text { Purchase } \\
\text { Behaviour } \\
\text { (Y) }\end{array}$} & $\begin{array}{l}\text { - When there is a choice, I always } \\
\text { choose products that } \\
\text { contribute the least to } \\
\text { environmental pollution }\end{array}$ & 5,160 & 1,312 & 1 & 7 & $\begin{array}{l}\text { (Chan, } \\
\text { 2001). }\end{array}$ & 0,9137 \\
\hline & $\begin{array}{l}\text { - If I understand the potential for } \\
\text { environmental damage caused } \\
\text { by some products, I don't buy } \\
\text { these products }\end{array}$ & 4,902 & 1,274 & 1 & 7 & & \\
\hline & $\begin{array}{l}\text { - I have switched to } \\
\text { environmentally friendly } \\
\text { products due to ecological } \\
\text { reasons }\end{array}$ & 4,727 & 1,157 & 1 & 7 & & \\
\hline & $\begin{array}{l}\text { - I have bought a product } \\
\text { because the product has less } \\
\text { pollution }\end{array}$ & 4,917 & 1,138 & 1 & 7 & & \\
\hline & $\begin{array}{l}\text { - If possible, I buy products that } \\
\text { are packaged in reusable } \\
\text { containers }\end{array}$ & 5,305 & 1,270 & 1 & 7 & & \\
\hline & $\begin{array}{l}\text { - When I buy products, I always } \\
\text { make a conscious effort to buy } \\
\text { products that are low in } \\
\text { pollutants }\end{array}$ & 5,082 & 1,224 & 1 & 7 & & \\
\hline & $\begin{array}{l}\text { - When I have a choice between } \\
\text { the same two products, I } \\
\text { always buy products that are } \\
\text { less harmful to others and the } \\
\text { environment }\end{array}$ & 5,320 & 1,263 & 1 & 7 & & \\
\hline & $\begin{array}{l}\text { - I only try to buy products that } \\
\text { can be recycled }\end{array}$ & & & & & & \\
\hline
\end{tabular}


In SEM analysis there is no single statistical test tool to measure or test hypotheses about the model (Hair et al., 1995). Generally against various types of fit indexes used to measure the degree of agreement between the hypothesized models and the data presented. Researchers are expected to conduct tests using several fit indexes to measure the truth of the proposed model.

Measurement of the Goodness of fit model by confirming construct validity. First, the psychometric nature of the proposed scale is assessed by conducting confirmatory factor analysis (Anderson \& Gerbing, 1988). Unidimensionality of the construct was confirmed for all items adopted. The Tucker Lewis Index is an alternative incremental fit index that compares a model tested against a baseline model. Comparative Fit index the magnitude of this index is in the range of 0-1 where getting closer to 1 indicates the highest level of fit (Arbukle, 1997). The results are as in table 6 The Goodness of Fit Model below shows that the comparative fit index (CFI) and Tucker-Lewis index (TLI) show values of 0,864 and 0,853 close to 0,9 . Thus, the measurement model is categorized as marginal fit with data.

Table 6. Goodness of Fit Model

\begin{tabular}{cccl}
\hline Fit Statistic & & Value & \multicolumn{1}{c}{ Description } \\
\hline Baseline Comparison & & & \\
& CFI & 0,864 & Comparative Fit Index \\
& TLI & 0,853 & Tucker-Lewis Index \\
\hline
\end{tabular}

\section{Structural Model}

The results of structural equation modeling shows that the hypotheses proposed are all supported, based on the results obtained in Figure 2 and Table 5.

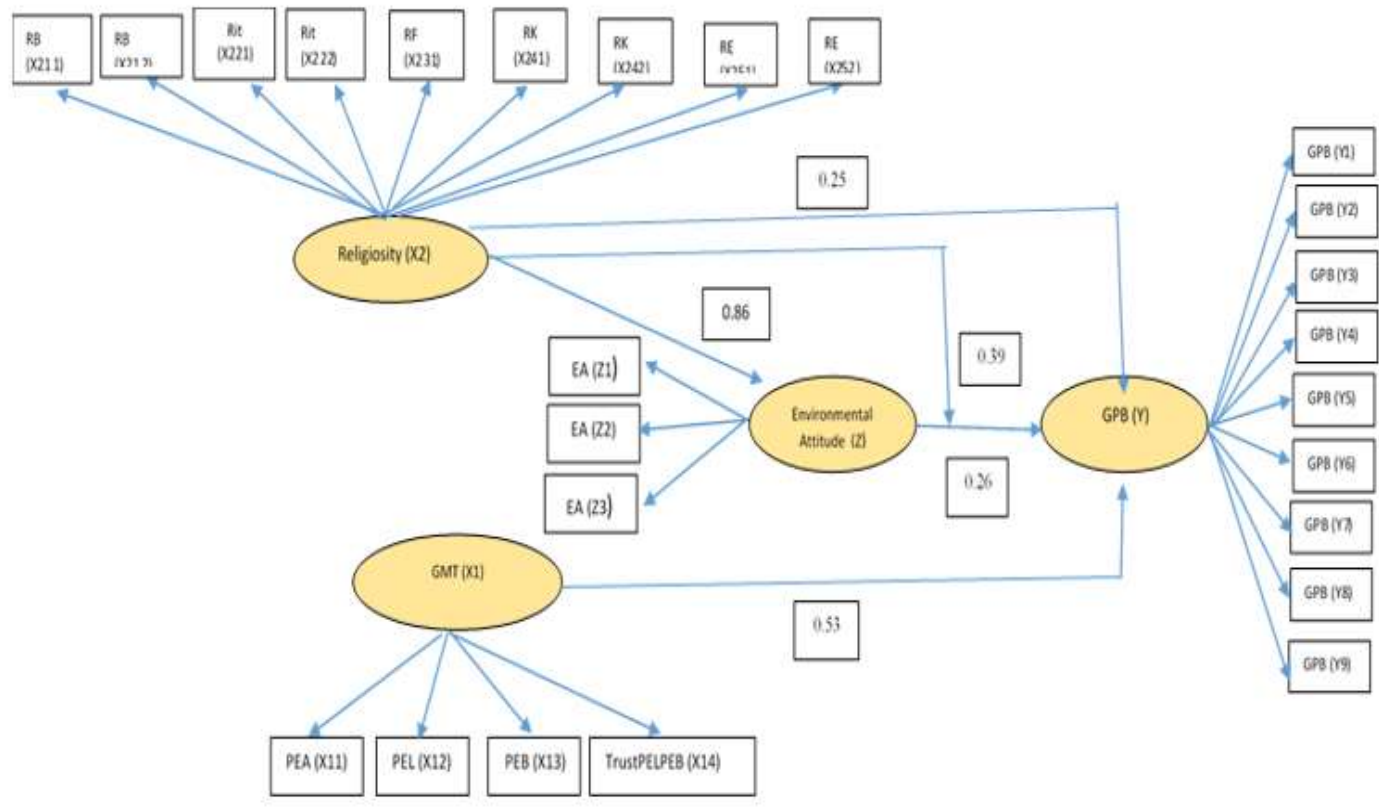

Figure 2. Structural Model

242 Management and Economics Journal (MEC-J) Vol 4 (3) December 2020 
Solekah, Premananto, Hartini

Table 7. Hypothesis Effect

\begin{tabular}{|c|c|c|c|c|c|}
\hline Hypothesis & Hypothesis effect & Coefficient & $\begin{array}{l}Z \\
\text { value }\end{array}$ & $\begin{array}{l}P \\
\text { value }\end{array}$ & Decision \\
\hline $\begin{array}{l}\mathrm{H} 1 \\
\mathrm{GMT} \rightarrow \mathrm{GBP}\end{array}$ & $\begin{array}{l}\text { The greater green } \\
\text { marketing tools which } \\
\text { consist of Environmental } \\
\text { Advertisement, } \\
\text { Perception of eco labels, } \\
\text { Perception of eco brand, } \\
\text { Trust in eco label and } \\
\text { eco brand the greater } \\
\text { possibility to influence } \\
\text { Green Behavioral } \\
\text { Purchase (GBP). }\end{array}$ & $0,533^{* * *}$ & 8,28 & 0,000 & Supported \\
\hline $\begin{array}{l}\mathrm{H} 2 \\
\mathrm{EA} \rightarrow \mathrm{GBP}\end{array}$ & $\begin{array}{l}\text { The greater } \\
\text { Environmental Attitudes } \\
\text { (EA) which consist of } \\
\text { Environmental } \\
\text { Knowledge (EK) and } \\
\text { Environmental Value } \\
\text { (EV) the greater } \\
\text { positive effect on } \\
\text { Green Behavioral } \\
\text { Purchase (GBP), }\end{array}$ & $0,261^{*}$ & 2,13 & 0,033 & Supported \\
\hline $\begin{array}{l}\text { H3 } \\
\text { RELIGIUSITY } \rightarrow \text { EA }\end{array}$ & $\begin{array}{l}\text { The greater religiosity } \\
\text { value which consist of } \\
\text { (religious belief), } \\
\text { experiential ritualistic } \\
\text { (religious feeling), } \\
\text { Intellectual (religious } \\
\text { knowledge), application } \\
\text { consequences of } \\
\text { religious effect the } \\
\text { greater } \\
\text { environmentally } \\
\text { friendly attitude }\end{array}$ & $0,865 * * *$ & 40,36 & 0,000 & Supported \\
\hline $\begin{array}{l}\mathrm{H} 4 \\
\text { RELIGIOSITY } \rightarrow \text { GBP }\end{array}$ & 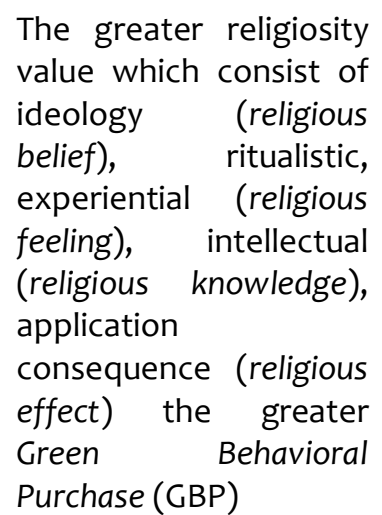 & $0,252^{*}$ & 1,97 & 0,049 & Supported \\
\hline
\end{tabular}

* The coefficient is statistically significant at $p<0,05 . * *$ The coefficient is statistically significant at $\mathrm{p}<0,01 . * * *$ The coefficient is statistically significant at $\mathrm{p}<0,001$ 
The greater the Green marketing tools measured by the indicators Environmental advertisement (X1.1), perception of eco labels (X1.2), Perception of eco brands (X1.3), Trust in eco labels and eco brands (X1.4) increasingly it is likely to influence Green Behavioral Purchase (GBP) with a coefficient of 0,533 ( $z$ value $=8,28$ statistically significant at $\mathrm{p}<0,001)$ so it supports the hypothesis H1. Green Marketing Tools (GMT) has a positive effect on Green Behavioral Purchase (GBP).

The greater Environmental Attitude (EA) which is psychological tendency expressed by evaluative responses to the natural environment with some level of likes or dislikes influencing Green Behavioral Purchase (GBP) with coefficient of 0,261 ( $z$ value $=2,13$ statistically significant at $\mathrm{p}<0,05$.) So it supports for $\mathrm{H} 2$. Environmental Attitudes (EA) has a positive effect on Green Behavioral Purchase (GBP).

For the variable Variability of Religiosity measured by ideological indicators (religious belief), Ritualistic, Exception (religious feeling), Intellectual (religious knowledge), Consequences of application (religious effect) have positive effect on Environmental Attitudes (EA) with coefficient of 0,865 ( $z$ value) $=0,865$ statistically significant at $p$ $<0,001)$ so that supporting $\mathrm{H}_{3}$ Religiosity has positive effect on Environmental Attitudes (EA)

The greater Religiosity measured by ideological indicators (religious belief), Ritualistic, Exception (religious feeling), Intellectual (religious knowledge), Consequences of application (religious effect) the greater the effect on having positive influence on Green Behavioral Purchase (GBP) with a coefficient of 0,252 ( $z$ value $=1,97$ is statistically significant at $\mathrm{p}<0,05)$ so that it supports H.4. Religiosity has a positive effect on Green Behavioral Purchase (GBP).

The results showed that Green marketing generally focuses on the efficiency of strategies of cognitive aspects that are persuasive, and believes that high consumer involvement on environmental issues is influenced by increased environmental knowledge. Hartmann and Iba'nez (2006) with Perception of Environmental Advertisement indicator is to influence consumers buying behavior by encouraging them to buy products that do not damage the environment and directing their attention to the positive consequences of their purchasing behavior, for themselves and also the environment (Davis, 1994), Perception of Eco labels where eco-labels as tool for consumers to facilitate the decision to choose environmentally friendly products also allows them to know how products are made, Rex and Baumann (2007), Perception of Eco -brand where Eco-brand is a name, symbol or product design that is not harmful to the environment (AMA) as well as Trust in eco labels and eco brands (Trust PELPEB) or trust that is defined as beliefs or expectations about environmental performance of environmental labels and environmental brands These give influence uh against Green Purchase Behavior (GPB).

The study results showed that millennial generation in shaping their engagement behavior on environmental issues is influenced by environmentally friendly advertisements, attributes or labels used on a product, then perceptions of 
environmentally friendly brands and trust in environmentally friendly advertisements, trust in compliance or environmentally friendly labels and brands that are on the products they know. Therefore this study supports the results of a previous study by Nik (2009) eco-label is an interesting instrument that informs consumers about the environmental impact of their purchasing decisions. The results of this study contradict one reason for this ineffectiveness is the lack of consumer confidence in eco-label schemes (Schwartz and Miller, 1991).

In line with the results above, the objective of environmental advertisements is to influence consumer purchasing behavior by encouraging them to buy products that do not harm the environment and directing their attention to the positive consequences of their purchasing behavior, both for themselves and the environment, which have significant impact on purchasing behavior. environmentally friendly on millennial generation itself these results support Davis (1994) and Baldwin (1993), environmental advertising helps shape consumer values and translates these values into purchasing green products. Likewise the results of this study support Chase and Smith (1992), environmental messages in advertising and product labeling were found to "sometimes" influence respondents purchasing decisions. But contrary to the same study, more than half of respondents indicated that they paid less attention to these messages because of over-use, and most respondents reported that environmental advertising was not credible.

The study results showed that environmental attitude (EA) which is a psychological tendency expressed by evaluative responses to the natural environment with several levels of likes or dislikes (Milfont \& Duckitt, 2010) with indicators of environmental knowledge (EK) which is the amount of information owned by individuals regarding environmental issues and their ability to understand and evaluate their impact on society and the environment. As well as environmental values which are personal values such as self transcendence which include universalism, altruism and virtue are asked to positively move ethical obligations and personal norms ( Chen and Chang, 2012; Eze et al., 2013; Padel and Foster, 2005) influence the green purchase behavior purchase (GPB) in millennial generation. This result does not support some previous studies which did not find relationship between factual environmental knowledge and ecological behavior (Maloney \& Ward, 1973; Maloney et al., 1975).

From the results of previous data analysis, this study showed that religiosity with indicators consisting of ideological (religious belief), ritualistic, spiritual (religious feeling), intellectual (religious knowledge), the consequences of implementation (religious effect) has an influence on environmental attitude (EA). This shows that indicators or experiential dimensions (religious beliefs) that focus on personal faith experiences, perhaps transcendent experiences, and ritual areas involve worship experiences involved in the community, Glock and Stark (1968), as well as Ritualistic indicators (religious exclusivity) involving experiences millennial generation worship and community involvement, ideological (religious feeling) based on the expectation that religion will hold to certain beliefs, Glock and Stark (1968), intellectual (religious knowledge) that have a relationship with the hope that religious people will be informed 
and knowledgeable regarding the basic principles of faith and the scriptures, consequential indicators (religious effects) which are all religious prescriptions that determine what people have to do and the attitudes they must hold as a consequence of their religion, Glock and Stark (1968) are factors that provide important influences tend towards psychological distress expressed by evaluative responses to the natural environment with some degree of like or dislike (Milfont \& Duckitt, 2010) in millennial generation.

The research shows that religiosity with indicators that consist of ideology (religious belief), ritualistic, experiential (religious feeling), intellectual (religious knowledge), application consequences (religious effect) have effects on Green Behavioral Purchase (GBP). It shows that the millennial generation seen from the ritualistic indicator This shows that millennial generation seen from the ritualistic indicator recognizes that one form of practicing religious teachings is to maintain the continuity of the environment and by doing so has carried out God's commands. The religious feeling indicator shows that being friendly to the environment will give a sense of calm and close to religion. From the indicators of Intellectual (religious knowledge) millennial generation knows that in the religious scriptures many explain the commands and prohibitions to act friendly to the environment and in them there are commands to preserve the sustainability of the environment for the future of future generations.

From the indicator of application consequences (religious effect) comes the awareness that behavior that causes environmental damage will have consequences, and realizes that the damage on this earth is the result of human actions. The results of this study are consistent with Esso and Dibb (2004) which states that religiosity influences consumer behavior in making purchases.

\section{CONCLUSION}

Green marketing tools (GMT) consisting of Environmental Advertisement, Perception of eco labels, Perception of eco brands, Trust in eco labels and eco brands affecting Green Behavioral Purchase (GBP) on millennial generation. Environmental Attitude (EA) which is psychological tendency expressed by evaluative responses to the natural environment with some degree of like or dislike affect Green Behavioral Purchase (GBP) on millennial generation. Religiosity measured by ideological indicators (religious belief), ritualistic, experiential (religious feeling), intellectual (religious knowledge), application consequences (religious effect) has positive effect on Environmental Attitudes (EA), this shows that the higher the religiosity millennial generation, the higher the influence on their attitudes towards the environment (Environmental Attitude).

This study results showed that religiosity with indicators consisting of ideological (religious belief), ritualistic, experiential (religious feeling), intellectual (religious knowledge), the application consequences (religious effect) has an influence on Green Behavioral Purchase (GBP). This shows that millennial generation seen from ritualistic indicators recognizes that one form of practicing religious teachings is to maintain the continuity of the environment and by doing so has carried out God's commands. In 
accordance with the study main objective, it was conducted by combining individual factors in the form of religious and situational factors in the form of green marketing tools in the form of eco labels, eco brands, trusts or trust in eco labels and eco brands, and environmental advertising results of this study can meet gap from some previous studies.

From the research results showed that green marketing tools and religiosity influence millennial generation attitudes towards the environment and influencing the purchase behavior of environmentally friendly products, showed that millennial generation is beginning to have awareness of green behaviors. Although all hypotheses tested showed significant results, it may be necessary to add additional variables both individually and situationally in the future. Besides that, it might be able to strengthen the religiosity value compared to the religious which is horizontally accepted for various religion. In the future, it is expected that green behavioral analysis that is associated with technological developments that is currently growing rapidly and psychological aspect.

\section{REFERENCES}

Allport, G.W. and Ross, J.M. (1967). Personal religious orientation and prejudice. Journal of Personality and Social Psychology, 5(4), 432-443.

Anderson, J.C.,\& Gerbing, D.W. (1988). Structural Equation Modeling in Practice : A Review and Recommendet Two-Step Approach. Psychological Buletin, 193(3), 411423.

Arbukle, J.L. (1997). Amos Users'Guide. Version 3.6. Chicago: Smallwaters Corporation.

Arnold, M. J. \& Reynolds, K. E. (2003). Hedonic shopping motivations. Journal of Retailing, 77-95

Asnawi, N dan Mashuri, M. (2011). Metodologi Riset Manajemen Pemasaran, Malang, UIN. Maliki PRESS.

Aytülkasapoglu, M. and Ecevit, M.C. (2002). Attitudes and behavior toward the environment: the case of Lake Burdur in Turkey. Environment and Behavior, 34(3), 363-377.

Baldwin, P. (1993). Advertisers beginning to see green. The Dallas Morning News, J1-J11

Bamberg, S. and Möser, G. (2007). Twenty years after Hines, Hungerford, and Tomera: a new meta-analysis of psycho-social determinants of pro-environmental behavior. Journal of Environmental Psychology, 27(1), 14-25.

Burgess, S.M. and Steenkamp, J.B.E.M. (2006). Marketing renaissance: how research in emerging markets advances marketing science and practice. International Journal of Research in Marketing, 23(4), 337-356. 
Chan, R. Y. (2001). Determinants of Chinese consumers' green purchase behavior. Psychology \& Marketing, 18(4), 389-413.

Chase, D. and Smith, T.K. (1992). Consumers keen on green but marketers don't deliver. Advertising Age, 63, June, 63.

Chen, Y. S., and Chang, C. H. (2012). Enhance green purchase intentions: The roles of green perceived value, green perceived risk, and green trust. Management Decision, 50(3), 502-520

Chen, Y. S. (2013). Towards green loyalty: Driving from green perceived value, green satisfaction, and green trust. Sustainable Development, 21(5), 294-308.

Davis, J.J. (1994). Consumer response to corporate environmental advertising. Journal of Consumer Marketing, 11(2), 25-37

Diamantopoulos, A., Schlegelmilch, B.B., Sinkovics, R.R. and Bohlen, G.M. (2003). Can socio demographics still play a role in profiling green consumers? A review of the evidence and an empirical investigation. Journal of Business Research, 56(6), 465480

Dröge, C., Calantone, R., Agrawal, M. and Mackoy, R. (1993). The consumption culture and its critiques: a framework for analysis. Journal of Macromarketing, 13(2), 32-45.

Delener, N. (1990). The effects of religious factors on perceived risk in durable goods purchase decisions. Journal of Consumer Marketing, 7(3), 27-38.

Delener, N. (1994). Religious contrasts in consumer decision behaviour patterns: their dimensions and marketing implications. European Journal of Marketing, 28(5), 3653.

Dembkowski, S. and Hanmer-Lloyd, S. (1994). The environmental value-attitude-system model: a framework to guide the understanding of environmentally-conscious consumer behavior. Journal of Marketing Management, 10(7), 593-603.

Elham Rahbar, Nabsiah Abdul Wahid, (2011). Investigation of green marketing tools' effect on consumers' purchase behavior. Business Strategy Series, 12(2), 73-83.

Essoo, N. and Dibb, S. (2004). Religious influence on shopping behavior : an exploratory study. Journal of Marketing Management, 20(7-8), 683-712.

Eze, U. C., \& Ndubisi, N. O. (2013). Green Buyer Behavior: Evidence from Asia Consumers. Journal of Asian and African Studies, 48(4), 413-426.

Fazio, R.H. and Zanna, M.P. (1978). Attitudinal qualities relating to the strength of the attitudebehavior relationship. Journal of Experimental Social Psychology, 14(4), 398-408.

Fraj, E. and Martinez, E. (2006). Environmental values and lifestyles as determining factors of ecological consumer behaviour: an empirical analysis. Journal of Consumer Marketing, 23(3), 133-144. 
Gatersleben, B., Steg, L. and Vlek, C. (2002). Measurement and determinants of environmentally significant consumer behavior. Environment and Behavior, 34(3), 335-362.

Ginsberg, J. and Bloom, P.N. (2004). Choosing the right green marketing strategy. MIT Sloan Management Review, 46(1), 79-84.

Glasman, L.R. and Albarracín, D. (2006). Forming attitudes that predict behavior: a meta analysis of the attitude-behavior relation. Psychological Bulletin, 132(5), 778-822.

Glock, C., Stark, R. (1968). American Piety: The Nature of Religious Commitment. University of California Press.

Grewal, D. and Levy, M. (2008). Marketing. McGraw-Hill/Irwin, New York, NY.

Harper, C.L. (2008). Religion and environmentalism. Journal of Religion \& Society, S3, 526, availableat:http://moses.creighton.edu/jrs/toc/SSo3.html.

Hartmann, P. and Iba 'n ez, V.A. (2006). Green value added. Marketing Intelligence \& Planning, 24(7), 673-80.

Hair,J.F., Anderson, R.E.Tatham,R.L \& Black,W.C. (1995). Multivariate Data Analysis (Fourth ed). New Jersey:Prentice Hall

Holland, R.W., Verplanken, B. and Van Knippenberg, A. (2002). On the nature of attitudebehavior relations: the strong guide, the weak follow. European Journal of Social Psychology, 32(6), 869-876.

Homer, P.M. and Kahle, L.R. (1988). A structural equation test of the value-attitudebehavior hierarchy. Journal of Personality and Social Psychology, 54(4), 638-646.

Hood, M. (2012). The big shift: the next generation has arrived. Direct Selling News, January, 10-14.

Jansson, J., Marell, A. and Nordlund, A. (2010). Green consumer behavior: determinants of curtailment and eco-innovation adoption. Journal of Consumer Marketing, 27(4), 358-370.

Joshi $Y$ and Rahman, Z. (2015). Factors Affecting Green Purchase Behaviour and Future Research Directions., International Strategic Management Review, 3(1-2), 128-143.

Kaiser, F.G., Wölfing, S. and Fuhrer, U. (1999). Environmental attitude and ecological behavior. Journal of Environmental Psychology, 19(1), 1-19.

Kalafatis,S.P., Pollard,M., East,R. and Tsogas,M.H. (1999). Green marketing and Ajzen's theory of planned behavior: across-market examination. Journal of Consumer Marketing, 16(5), 441-460.

Kim, Y. and Choi, S. M. (2005). Antecedents of green purchase behavior: an examination of collectivism, environmental concern, and PCE. Advances in Consumer Research, 32, 592-599. 
Lee, K. (2008). Opportunities for green marketing: young consumers. Marketing Intelligence \& Planning, 26(6), 573-86.

Maloney, M. P. \& Ward, M. P. (1973). Ecology: let's hear from the people. An objective scale for the measurement of ecological attitudes and knowledge. American Psychologist 28, 583-586.

Maloney, M. P., Ward, M. P. \& Braucht, G. N. (1975). Psychology in action: a revised scale for the measurement of ecological attitudes and knowledge. American Psychologist 30, 787-790.

McCarty, J.A. and Shrum, L.J. (2001). The influence of individualism, collectivism, and locus of control on environmental beliefs and behavior. Journal of Public Policy \& Marketing, 20(1), 93-104.

Martin, E. (2012). Move over. BRICs. Here come the MISTs. Bloomberg Business, August 9, available at: www.bloomberg.com/bw/articles/2012-08-09/move-over-brics-dothere-comethe-mists (accessed January 22, 2012).

Martin, W.C. and Bateman, C.R. (2014). Consumer religious commitment's influence on econcentric attitudes and behavior. Journal of Business Research, 67(2) 5-11.

McKay, L. (2010). Generation green: why Gen $Y$ and the Millennials are greener than you'll ever be. CRM Magazine, 14(4), 12.

Meinhold, J.L. and Malkus, A. J. (2005). Adolescent environmental behaviors: can knowledge, attitude, and self-efficacy make a difference?. Environment and Behavior, 37(4), 511-532.

Milfont, L., \& Duckitt, J. (2004). The structure of environmental attitudes: Afirst-and second-order confirmatory factor analysis. Journal of Environmental Psychology, 24, 289-303.

Milfont, T. L., \& Duckitt, J. (2010). The environmental attitudes in-ventory: A valid and reliable measure to assess the structure ofenvironmental attitudes. Journal of Environmental Psychology,30, 80-94.

Millar, M. G. and Tesser, A. (1989). The effects of affective-cognitive consistency and thought on the attitude-behavior relation. Journal of Experimental Social Psychology, 25(2), 189-202.

Minton, A. P. and Rose, R. L. (1997). The effects of environmental concern on environmentally friendly consumer behavior: an exploratory study. Journal of Business Research, 40(1), 37-48.

Nik A. R. N. R. (2009). Awareness of eco-label in Malaysia's green marketing initiative. International Journal of Business and Management, 4(8), 132-41.

Padel, S., \& Foster, C. (2005). Exploring the gap between attitudes and behaviour: Understanding why consumers buy or do not buy organic food. British food journal, 107(8), 606-625. 
Rex, E., and Baumann, H. (2007). Beyond Eco-labels: what green marketing can learn from conventional marketing. Journal of Cleaner Production, 15(6), 567-576.

Roberts, J. A. (1996). Green consumers in the 1990s: profile and implications for advertising. Journal of Business Research, 36(3), 217-231.

Schäfer, M., Jaeger-Erben, M. and Dos Santos, A. (2011). Leapfrogging to sustainable consumption? An explorative survey of consumption habits and orientations in Southern Brazil. Journal of Consumer Policy, 34(1), 175-196.

Schlegelmilch, B. B., Bohlen, G. M. and Diamantopoulus, A. (1996). The link between green purchasing decisions and measures of environmental consciousness. European Journal of Marketing, 30(5), 35-55. 6-35.

Schrum, L. J., McCarty, J. A. and Lowrey, T. M. (1995). Buyer characteristics of the green consumer and their implications for advertising tool. Journal of Advertising, 24(2), 71-82.

Schultz, P. W. and Oskamp, S. (1996). Effortasa moderatoroftheattitude-behavior relationship: general environmental concern and recycling. Social Psychology Quarterly, 59(4), 375-383.

Schwartz, J. and Miller, T. (1991). The earth's best friends. American Demographics, 13 February, 2 .

Smith, K. T. and Brower, T. R. (2012). Longitudinal study of green marketing strategies that influence Millennials. Journal of Strategic Marketing, 20(6), 535-551.

Stanton, W. J. and Futrell, C. (1987). Fundamentals of Marketing. 8th edition. New York: McGraw-Hill Book Company.

Soyez, K. (2012). How national cultural values affect pro-environmental consumer behavior. International Marketing Review, 29(6), 623-646.

Sumarwan, U. (2011). Perilaku Konsumen Teori Dan Penerapannya Dalam Pemasaran. Bogor: PT Ghalia Indonesia.

Tanner, C. and Wölfing K. S. (2003). Promoting sustainable consumption: determinants of green purchases by Swiss consumers. Psychology and Marketing, 20(10), 883902.

Wicker, A. W. (1969). Attitudes versus actions: the relationship of verbal and overt behavioral responses to attitude objects. Journal of Social Issues, 25(4), 41-78.

Wilson, T. D. and Dunn, D. S. (1986). Effects of introspection on attitude-behavior consistency: analyzing reason versus focusing on feelings. Journal of Experimental Social Psychology, 22(3), 249-263.

Wong, V., Turner, W. and Stoneman, P. (1996). Marketing strategies and market prospects for environmentally-friendly consumer products. British Journal of Management, 7(3), 263-81. 
Green Marketing Tools, Religiosity, Environmental Attitude ......

Zanna, M. P., Olson, J. M. and Fazio, R. H. (1980). Attitude-behavior consistency: an individual difference perspective. Journal of Personality and Social Psychology, 38(3), 432-440. 